\title{
Reactivity and Leaching of Wood Ash Pellets Dehydrated by Hot Air and Flue Gas
}

\author{
S. Sarenbo*, P. Mellbo, O. Stålnacke and T. Claesson \\ University of Kalmar, School of Pure and Applied Natural Sciences, 39182 Kalmar, Sweden
}

\begin{abstract}
Companies that generate a large amount of wood ash will need an industrial process to agglomerate the ash and lower its reactivity, because untreated ash is a dust hazard for workers and is difficult to spread evenly on forest soil. In addition, untreated ash can cause burning damage to vegetation owing to its alkalinity and rapid release of salts. Production of large amounts of wood ash agglomerates demands an effective dehydration process. The reactivity and release of inorganic constituents from wood ash pellets dehydrated at room temperature using hot air and flue gas was investigated. Our results imply that flue gas-treated pellets have significantly lower reactivity in terms of $\mathrm{pH}$ and electrical conductivity, and release less $\mathrm{Ca}^{2+}$ and more $\mathrm{Mg}^{2+}$ compared to pellets dried at room temperature or in hot air. Ash pellets dehydrated in hot air are very reactive, and release more $\mathrm{Ca}^{2+}$ than pellets dried in other ways. The formation of syngenite during the flue-gas treatment decreases $\mathrm{K}^{+}$release from the ash pellets.
\end{abstract}

Keywords: Wood ash, ash pellet, leaching, dehydration, carbonation, reactivity.

\section{INTRODUCTION}

The recycling of ash from wood combustion back to the forest floor has been suggested as a method of closing the cycle for non-combustible matter, i.e., mineral nutrients. However, practical handling of ash materials may involve a considerable dust source. Newly generated, untreated wood ash can also have an adverse effect the ground vegetation from burning damage owing to its reactivity $[1,2]$, along with an increase in soil respiration and microbial activity [3, 4]. Therefore, it is necessary to pre-treat the ash to lower its reactivity. The purpose of pre-treatment is to facilitate the practical management of the ash, to decrease dust formation, and to prolong the decomposition time of ash particles. Ideally, the rate of decomposition of the recycled ash particles should match that of the natural decomposition of forest residues, such as needles, leaves, and branches. It is possible to process hydrated ash to form small spherical granules by granulation, or to press a hydrated ash mixture into pellets in a pelletizer. It is also possible to "self-harden" hydrated wood ash in a pile outdoors over the period of a year; then the ash is crushed and sieved. The crushed ash agglomerates are then spread in a forest. The drawbacks of this method are that it requires space, it is time consuming, and it creates dust problems during the handling operations.

\section{HYDRATION AND CARBONATION}

The crystalline phases observed in untreated wood ash include, among others, calcium oxide $(\mathrm{CaO})$, calcite $\left(\mathrm{CaCO}_{3}\right)$, portlandite $\left(\mathrm{Ca}(\mathrm{OH})_{2}\right)$, anhydrite $\left(\mathrm{CaSO}_{4}\right)$, and larnite $\left(\mathrm{Ca}_{2} \mathrm{SiO}_{4}\right)$ [5-8]. However, calcium oxide and portlandite are the main constituents of untreated fresh wood ash, with as much as $30 \mathrm{wt} \%$. This is responsible for the

*Address correspondence to this author at the University of Kalmar, School of Pure and Applied Natural Sciences, 39182 Kalmar, Sweden; Tel +46480447353; Fax: +46480447300; E-mail: sirkku.sarenbo@hik.se most important reactions during the hydration and carbonation of ash materials. Hydration of $\mathrm{CaO}$ is a rapid and exothermic reaction that forms portlandite, $\mathrm{Ca}(\mathrm{OH})_{2}$, (Eq. 1), which precipitates in a crystalline form. The formation of other hydration minerals, e.g., ettringite (Eq. 2) and gypsum (Eq. 3), is also possible, depending on the origin and the properties of the ash, and on whether additives have been used. Ettringite is the phase that crystallizes during the hydration of tricalcium aluminate (the main crystalline phase of cements) when sulphate ions are present. As well, it is the main hydrated phase in many other cementitious materials [9]. The formation of ettringite in wood ash depends on the aluminum content of the ash (as $\mathrm{Al}_{2} \mathrm{O}_{3}$ ) exceeding the sulphur content, with the ash pore solution having $\mathrm{pH}>11$ [10]. The formation of gypsum from anhydrite occurs if the conditions for ettringite formation are not suitable [6]. The hydration reactions are followed by a carbonation process, where portlandite reacts with available (atmospheric) $\mathrm{CO}_{2}$ to form calcium carbonate, $\mathrm{CaCO}_{3}$ (Eq. 4). This process is a liquid-phase reaction of carbon dioxide with aqueous hydroxide and cations to produce carbonates [11]. The formation of other carbonate phases is also possible. For example, Steenari and Lindqvist [6] observed $\mathrm{CaAl}_{2}\left(\mathrm{CO}_{3}\right)_{2} \cdot 6 \mathrm{H}_{2} \mathrm{O}$ and $\mathrm{CaCO}_{3} \cdot \mathrm{H}_{2} \mathrm{O}$ in biofuel ashes. The former product was suggested to be the result of a reaction of ettringite with $\mathrm{CO}_{2}$.

During production of cement mortars, the water:cement ratio is critical, in that sufficient moisture must be present for carbonation to occur rapidly, but there must not be too much, as it could fill any pores and impede the diffusion of $\mathrm{CO}_{2}$ into the sample [12]. Similarly, the hydration of wood ash is a critical moment during the manufacturing of wood ash agglomerates [13], both in terms of the physical formation of agglomerates and the chemical reactions on the addition of water. Too much water hinders the physical formation of agglomerates (i.e., the mixture becomes a slurry), and too little water impedes the adherence of the particles during dehydration. The required range of water addition is narrow, 
as demonstrated by Svantesson [13]. The addition of 2-4 litres of water to $250-300 \mathrm{~kg}$ of a saturated batch of ash results in a mixture that is too wet. In turn, the chemical reactions decrease the reactivity of ash materials by lowering their electrical conductivity, $\mathrm{pH}$, and dissolution kinetics. In addition, the mechanical strength of the material is enhanced.

$$
\begin{aligned}
& \mathrm{CaO}+\mathrm{H}_{2} \mathrm{O} \rightarrow \mathrm{Ca}(\mathrm{OH})_{2} \\
& \mathrm{Ca}_{3} \mathrm{Al}_{2} \mathrm{O}_{6}+3 \mathrm{CaSO}_{4} \cdot 2 \mathrm{H}_{2} \mathrm{O}+26 \mathrm{H}_{2} \mathrm{O} \rightarrow \\
& \mathrm{Ca}_{6} \mathrm{Al}_{2}\left(\mathrm{SO}_{4}\right)_{3}(\mathrm{OH})_{12} \cdot 26 \mathrm{H}_{2} \mathrm{O} \\
& \mathrm{CaSO}_{4}+2 \mathrm{H}_{2} \mathrm{O} \rightarrow \mathrm{CaSO}_{4} \cdot 2 \mathrm{H}_{2} \mathrm{O} \\
& \mathrm{Ca}(\mathrm{OH})_{2}+\mathrm{CO}_{2} \rightarrow \mathrm{CaCO}_{3}+\mathrm{H}_{2} \mathrm{O}
\end{aligned}
$$

Water is liberated during carbonation and becomes available for any non-reacted material. In a manner similar to Portland cement, the ash material undergoes chemical changes during the course of time and "ages". The carbonation of cement matrices has a significant physical effect on the mass transport properties of these materials through a narrowing of the pore structure due to the increase in solid volume (11\%-12\%) expected when portlandite is converted to calcium carbonate [11]. The carbonation of cement and concrete is not desirable because it causes a cracking of the structures and a reduction in strength. However, in the context of wood ash recycling, at least a partial carbonation is desirable to decrease the material reactivity and to slow down its dissolution kinetics.

\section{ACCELERATED CARBONATION}

Accelerated carbonation using gas containing $\mathrm{CO}_{2}$ at a concentration between $5 \%$ and $100 \%$ is used in cement chemistry $[12,14]$ and in research into residues from municipal solid waste incineration (MSWI) $[15,16]$ to fix the time of testing. The $\mathrm{CO}_{2}$ source used can be either pure $\mathrm{CO}_{2}$ gas or any other $\mathrm{CO}_{2}$-rich gas, such as the flue gas from incineration [16]. The approximate concentration of $\mathrm{CO}_{2}$ in air is $0.035 \%$, and the carbonation depth of structural concretes occurs at the rate of $1 \mathrm{~cm}$ per year [11]. It has been shown that the carbonation of cementitious materials, such as MSWI fly ash, occurs in minutes when exposed to high concentrations of $\mathrm{CO}_{2}[16]$.

To ensure effective agglomeration, it is necessary to dehydrate ash products rapidly, as this enables immediate packing and distribution. Very little research has been carried out on the influence of dehydration methods on the chemical properties of wood ash agglomerates with respect to their reactivity and the release of inorganic constituents. There have been examples of drying biofuels using flue gas $[17,18]$, and the utilization of hot air and flue gas to dehydrate ash has been discussed in the literature [13]. We found only a single report concerning treatment of wood ash products with different drying media in a literature search. The results of Holmberg et al. [19] imply that the calcite content is higher and the portlandite and arcanite $\mathrm{K}_{2}\left(\mathrm{SO}_{4}\right)$ content slightly lower in wood ash granules treated using flue gas (11 -16 vol.\% $\left.\mathrm{CO}_{2}\right)$ from sawdust combustion compared to those dried using only hot air. In addition, fluegas drying did not affect the chemical composition of the granules, and only changes in their mineralogy were observed. However, no leaching test results were presented.

\section{SCOPE AND OBJECTIVES}

In this paper, the reactivity and the leaching of wood ash pellets dehydrated using four different methods are compared. The aim was to produce ash pellets with as low reactivity as possible in terms of the $\mathrm{pH}, \mathrm{EC}$, and release of constituents upon first contact with water.

\section{MATERIALS AND METHODOLOGY}

Ash pellets were produced in industrial roll-pelletizing equipment by mixing $100 \mathrm{~kg}$ (fresh weight) of fly ash from a $40 \mathrm{MW}$ pulverized wood-fired boiler with $50 \mathrm{~kg}$ of dolomite powder (as a binder and adds $\mathrm{Mg}$ and $\mathrm{Ca}$ to the mixture) and $50 \mathrm{~kg}$ of water. The paste was then pressed and cut into pellets. Directly after pelletizing, the pellets were subjected to the following dehydration treatments:

1) Room temperature (Sample D20): $20{ }^{\circ} \mathrm{C}$ in the laboratory, in a $5 \mathrm{~cm}$-thick layer of ash pellets.

2) Hot air (Sample D60): $60{ }^{\circ} \mathrm{C}$, fan-forced air $\left(3000 \mathrm{~m}^{3}\right.$ $\left.\mathrm{h}^{-1}\right)$, in an oven for $120 \mathrm{~min}$, in an $8-10 \mathrm{~cm}$-thick layer of ash pellets.

3) Hot air (Sample D130): $130{ }^{\circ} \mathrm{C}$, in an oven for 10 min, in a $5 \mathrm{~cm}$-thick layer of ash pellets.

4) Flue gas (Sample DF): flue gas from the combustion of pulverized wood in a $40 \mathrm{MW}$ boiler (DF): $~ 130$ ${ }^{\circ} \mathrm{C}, 10-15 \% \mathrm{CO}_{2}$ and $\mathrm{H}_{2} \mathrm{O}$. The ash pellets were exposed perpendicular to the flue gas flow in a chimney, for a period of $10 \mathrm{~min}$ in stainless steel net bags.

After dehydration, all the pellet samples were stored in open vessels in the laboratory. After a period of $75 \mathrm{~d}$, the ash pellets were subjected to two different laboratory leaching tests: a compliance test and a reactivity test. All equipment was rinsed with $0.1 \mathrm{M}$ nitric acid before the leaching experiments were performed. The pellet samples were fractionated into the size interval $4-8 \mathrm{~mm}$ using a stainless steel mesh. The leaching tests were performed on five replicates for each sample.

Eluates from the reactivity test were analysed for $\mathrm{pH}$ and EC using a Metrohm $744 \mathrm{pH}$ Meter and a Jenway 4510 Conductivity Meter, respectively. Eluates from the compliance tests were conserved in concentrated nitric acid before analysis of the concentration of $\mathrm{Na}, \mathrm{Ca}, \mathrm{K}, \mathrm{Mg}, \mathrm{Mn}$, $\mathrm{Al}, \mathrm{Fe}, \mathrm{P}$, and $\mathrm{Zn}$. The analysis was carried out using inductively coupled plasma mass spectrometry, ICP-MS Perkin Elmer, Optima 3300 DV. The inorganic element content in the pellet samples was analysed at Acme Analytical Laboratories Ltd, Canada, employing a multi-acid digestion and inductively coupled plasma emission spectrometry (ICP-ES) and ICP-MS. The mineralogical composition was examined using X-ray diffraction (XRD), Siemens D5000, employing the data DIFFRAC PLUS evaluation programme and the on-line JCPDS database (PDF-4) located at the Environmental Inorganic Chemistry, Department of Chemical and Biological Engineering, Chalmers University of Technology, Göteborg, Sweden.

Ash pellets (length $=10 \mathrm{~mm}$, diameter $=5 \mathrm{~mm}$ ) were also produced manually from the ash by pressing wet ash paste 
through a plexiglass matrix. Before pellet production, the ash was ignited at $550{ }^{\circ} \mathrm{C}$ for a period of two hours to reduce the amount of organic matter. One fraction of the pellets was then subjected to flue gas for a period of $10 \mathrm{~min}$, and another fraction of ash pellets was subjected to hot air $\left(130^{\circ} \mathrm{C}\right)$ in an oven for a period of $10 \mathrm{~min}$, similar to the industrially produced pellets described above. The mineralogy of the untreated ash and pellets dehydrated using hot air and flue gas was determined using XRD as described above.

\section{Compliance Test EN12457-4}

The compliance test was used to determine whether the waste complied with specific reference values. The test is a single-stage batch test that is relatively rapid to perform, and assumes that a chemical equilibrium or a semi-equilibrium is achieved between the liquid and solid phases in the time period of the test. Compliance tests are also suitable for comparing properties of different materials. The material to be leached is placed in water in bottles, and agitated for a period of $24 \mathrm{~h}$, and then the eluate is analyzed. We performed our compliance tests with some modifications to this procedure: a test portion of $80 \mathrm{~g}$ rather than $90 \mathrm{~g}$ was subjected to leaching, and the L:S ratio was modified to L:S
$=5$ (the same L:S ratio as in the Swedish Forest Agency SFA reactivity test) instead of $\mathrm{L}: \mathrm{S}=10$. A horizontal platform shaker, with a reciprocating motion at $140 \mathrm{rpm}$ was used in the tests instead of an end-over-end tumbler.

\section{The SFA Reactivity Test}

This reactivity test was developed by the SFA [20]. Its purpose is to determine the chemical reactivity of a wood ash product before spreading. Ash is placed in a flask of water $(\mathrm{L}: \mathrm{S}=5)$ along with a magnetic stirrer, and the mixture is stirred for a period of $1 \mathrm{~h}$ (at $600 \mathrm{rpm}$ ). The eluate is then analyzed. The $\mathrm{pH}$ is measured directly in the eluate and the electrical conductivity of the eluate is measured after separation of the solid residue after filtering (Munktell filter paper No. 3). The dry substance of the ash pellets was determined according to the Swedish Standard SS 028113.

\section{Data Analysis}

Differences in the reactivity and leaching behavior between the pellets dehydrated using different methods were investigated using a Partial least squares regression (PLSR) technique, using the leached amounts as the $\mathrm{X}$ variables and the dummy variables indicating the chosen drying technique

Table 1. Average Concentration of Analytes in Industrially Produced Wood Ash Pellets Dehydrated Using Different Methods. (Standard Deviation is Given in Parentheses)

\begin{tabular}{|c|c|c|c|c|}
\hline$\%$ & Room Temp. & Hot Air $\left(60^{\circ} \mathrm{C}\right) 120 \mathrm{~min}$ & Hot Air $\left(130^{\circ} \mathrm{C}\right) 10 \mathrm{~min}$ & Flue Gas $10 \mathrm{~min}$ \\
\hline C (inorg.) & $20.8(0.23)$ & $19.9(0.70)$ & $20.7(0.53)$ & $20.8(0.56)$ \\
\hline $\mathbf{C a}$ & $17.1(0.36)$ & $17.3(0.24)$ & $17.3(0.33)$ & $17.3(0.26)$ \\
\hline Mg & $6.77(0.091)$ & $6.91(0.13)$ & $\mathbf{6 . 8 3}(0.30)$ & $6.87(0.15)$ \\
\hline $\mathbf{K}$ & $3.97(0.18)$ & $3.96(0.046)$ & $3.99(0.046)$ & $4.08(0.18)$ \\
\hline Al & $\mathbf{0 . 3 4 3}(0.0058)$ & $\mathbf{0 . 3 4 7}(0.015)$ & $\mathbf{0 . 3 5 3}(0.0058)$ & $\mathbf{0 . 3 4 3}(0.012)$ \\
\hline $\mathbf{P}$ & $\mathbf{0 . 2 9 6}(0.0061)$ & $\mathbf{0 . 2 9 9}(0.0025)$ & $\mathbf{0 . 3 0 8}(0.0076)$ & $\mathbf{0 . 3 1 3}(0.0070)$ \\
\hline $\mathrm{Na}$ & $\mathbf{0 . 2 2 3}(0.0087)$ & $\mathbf{0 . 2 2 5}(0.0064)$ & $\mathbf{0 . 2 2 7}(0.0068)$ & $\mathbf{0 . 2 2 9}(0.0061)$ \\
\hline $\mathrm{H}_{2} \mathrm{O}$ & $\mathbf{0 . 9 3}(0.99)$ & $1.2(0.59)$ & $\mathbf{0 . 7 5}(0.66)$ & $1.2(0.43)$ \\
\hline $\mathbf{Z n}$ & $425(11)$ & $426(2.7)$ & $428(5.0)$ & $433(12)$ \\
\hline B & $164(1.5)$ & $177(8.6)$ & $177(4.6)$ & $\mathbf{1 7 3}(9.1)$ \\
\hline $\mathbf{B a}$ & $79(1.7)$ & $85(2.1)$ & $91(4.7)$ & $95(7.6)$ \\
\hline $\mathrm{Cu}$ & $70(0.81)$ & $69(0.9)$ & $70(1.1)$ & $72(2.4)$ \\
\hline $\mathbf{P b}$ & $27(0.82)$ & $26(0.42)$ & $27(1.5)$ & $26(1.1)$ \\
\hline $\mathrm{Cr}$ & $29(11)$ & $22(1.7)$ & $22(1.0)$ & $21(0.42)$ \\
\hline $\mathrm{Ni}$ & $15(7.0)$ & $11(7.0)$ & $11(0.57)$ & $12(0.50)$ \\
\hline As & $1.5(0.2)$ & $\mathbf{1 . 1}(0.15)$ & $\mathbf{1 . 0}(0.058)$ & $1.3(0.21)$ \\
\hline
\end{tabular}




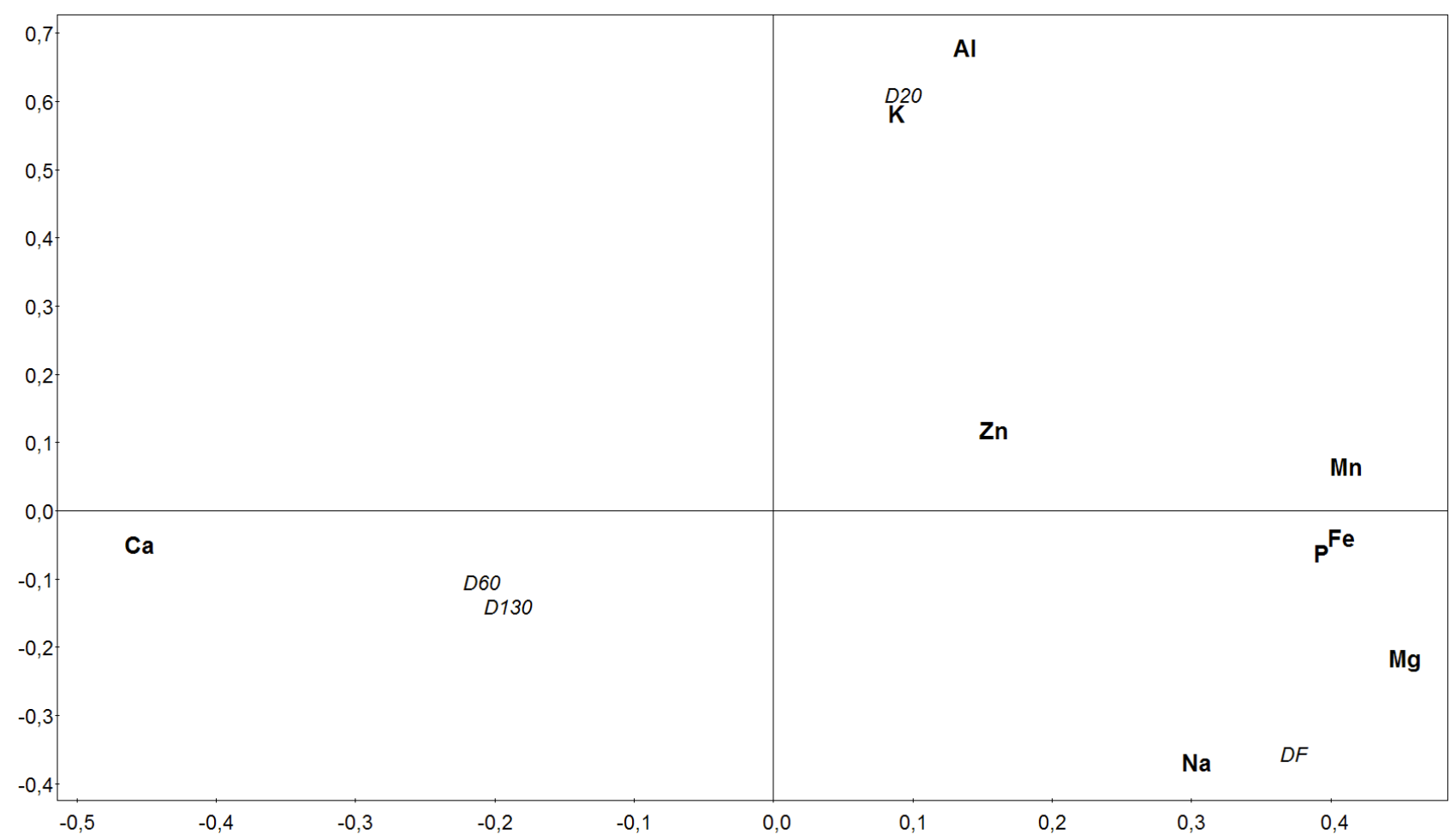

Fig. (1). Loadings from partial least squares regression of the leached percentage from industrially produced pellets with respect to the different dehydration methods used. Pellets dehydrated at room temperature (D20), using hot air (D60 and D130), and flue gas (DF). The $\mathrm{x}$ and $\mathrm{y}$ axes denote $\mathrm{w}^{*} \mathrm{c} 1$ and $\mathrm{w}^{*} \mathrm{c} 2$, respectively.

were the Y-variables. The significance of the observed differences was tested using the Tukey HSD post hoc test at the $P<0.05$ level.

\section{RESULTS}

\section{General Composition of Wood Ash Pellets}

The elemental composition of the ash pellets was uniform in all four cases. The main constituents of the pellets were $\mathrm{Ca}, \mathrm{Mg}$, and $\mathrm{K}$ as $17 \%, 7 \%$ and $4 \%(\mathrm{db})$, respectively (Table 1). Powdered dolomite was used as the binder in $33 \%$ by weight of fly ash for pelletization, and this altered the composition of the ash by adding $\mathrm{Ca}, \mathrm{Mg}$ and $\mathrm{Si}$ to the mixture, and lowering the concentration of many other elements, e.g., phosphorus, because of dilution. Consequently, the concentrations of trace elements, such as $\mathrm{Cd}, \mathrm{V}, \mathrm{Mo}$ and As were moderate. The content of inorganic carbon was high, at $20-21 \%(\mathrm{db})$, depending on the presence of dolomite. The moisture content of the pellet samples ranged from $0.75 \%$ to $1.2 \%$.

\section{Leaching of Elements}

Leaching tests were performed on five replicates for each sample of the industrially produced pellets and the reproducibility of the test procedure was verified as being good. The PLSR process resulted in two principal components describing $56 \%$ of the variation in the $Y$ variables, $80 \%$ of the variation in the $\mathrm{X}$ variables, and with a predictive ability of $50 \%\left(\mathrm{R}^{2} \mathrm{Y}=0.56, \mathrm{R}^{2} \mathrm{X}=0.80\right.$, and $\mathrm{Q}^{2}=$ $0.50)$. There were general differences in the leaching behavior between the ash pellets that had been dehydrated using different methods, indicated by the high $\mathrm{Q}^{2}$ value, and shown by the clear separation between the corresponding points in the loading plot (Fig. 1). Leaching from pellets dehydrated using hot air was uniform, regardless of temperature. Both the hot-air treatments produced pellets with a significantly higher release of Ca (Fig. 1; Table 2) compared to the pellets subjected to other treatments: they released twice as much $\mathrm{Ca}$ than the room-temperature dried pellets did and eight times more than the flue-gas treated pellets. There was a significantly higher release of $\mathrm{K}$ and $\mathrm{Al}$ from the pellets dehydrated at room temperature (Sample D20) compared to the other samples (Fig. 1; Table 2). The flue-gas treated pellets released significantly less $\mathrm{Ca}$ and more $\mathrm{Mg}$ compared to the pellets treated using other drying methods (Fig. 1; Table 2). The release of Mn, P, Fe, and $\mathrm{Zn}$ from all pellet types was insignificant.

\section{pH and EC}

There were also significant differences in the reactivity in terms of $\mathrm{pH}$ and $\mathrm{EC}$ between the pellet types. The $\mathrm{pH}$ in fluegas treated pellets was up to two units lower compared to pellets dehydrated using hot air and room temperature. Te hot-air dehydrated pellets had the highest EC (2020-2070 $\mathrm{mSm}^{-1}$; Table 2), with Sample D20 having an intermediate EC $\left(1700 \mathrm{mSm}^{-1}\right)$, and Sample DF the lowest EC $\left(1590 \mathrm{mSm}^{-1}\right)$.

\section{Mineralogy}

The crystalline compounds present in untreated fly ash are: calcite $\left(\mathrm{CaCO}_{3}\right)$, sylvite $(\mathrm{KCl})$, quartz $\left(\mathrm{SiO}_{2}\right)$, arcanite $\left(\mathrm{K}_{2} \mathrm{SO}_{4}\right)$, halite $(\mathrm{NaCl})$ and aphthitalite $\left(\mathrm{K}_{3} \mathrm{Na}\left(\mathrm{SO}_{4}\right)_{2}\right)$. In addition, 
Table 2. Concentration of Released Elements (in $\mathrm{mg} \mathrm{L}^{-1}$ ), $\mathrm{pH}$, and Electrical Conductivity (EC) of Industrially Produced Ash Pellets Dehydrated using Different Methods. (Standard Deviation is Given in Parentheses)

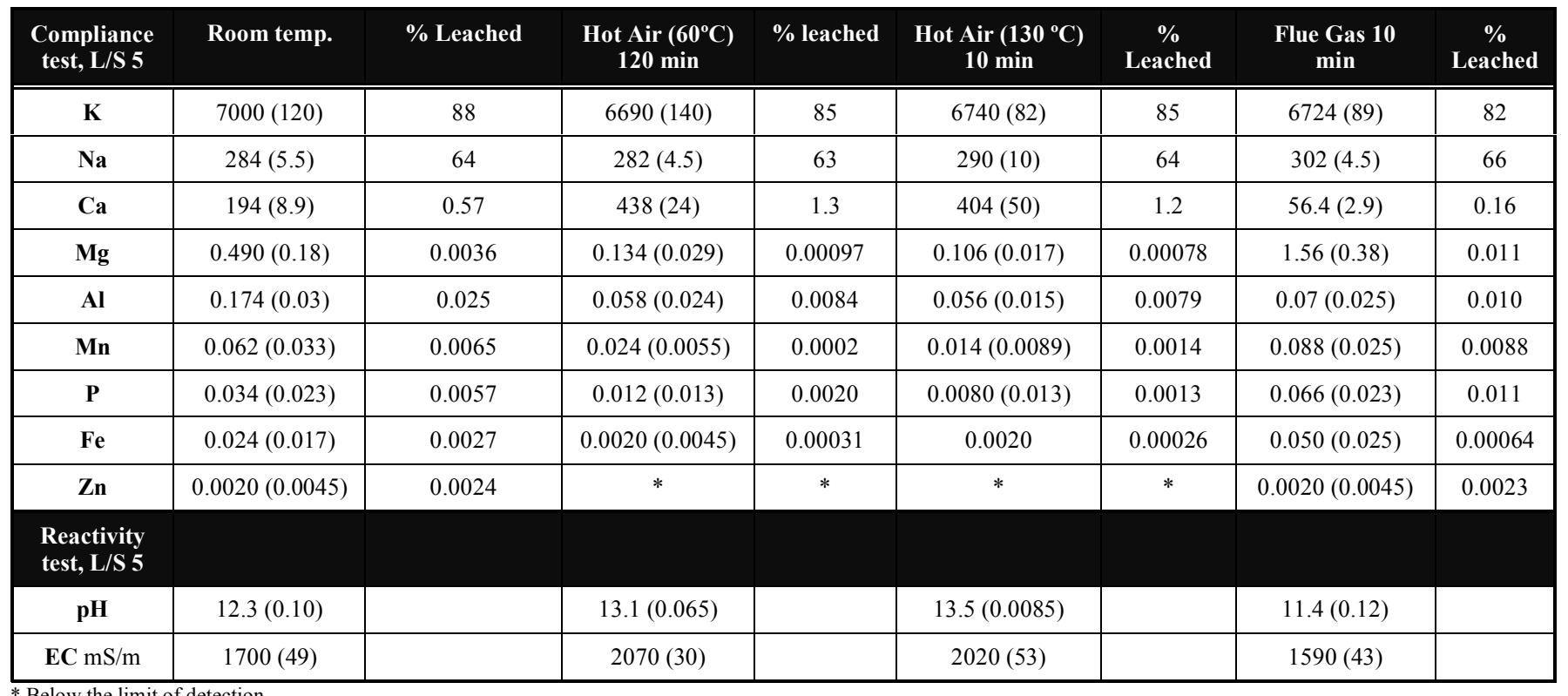

syngenite $\left(\mathrm{K}_{2} \mathrm{Ca}\left(\mathrm{SO}_{4}\right)_{2}\right)$ was also present in both the flue-gas and hot-air treated pellets (manually produced pellets). The mineralogy of the industrially produced pellets was the same in all samples: dolomite $\left(\mathrm{CaMg}\left(\mathrm{CO}_{3}\right)_{2}\right)$, calcite, quartz, and arcanite were observed in all samples (Fig. 2).

\section{DISCUSSION}

A rapid dehydration process increases the effectiveness of the production of ash pellets. It is favorable, in that the ash is also carbonated, because carbonation decreases the ash reactivity with regard to the $\mathrm{pH}$ and $\mathrm{EC}$, and prolongs the leaching of cations such as $\mathrm{Ca}$ from the ash matrix.

\section{Composition - Contamination}

The composition of the pellets subjected to different dehydration techniques was surprisingly uniform (Table 1). Dehydration during 10 minutes in the flue gas in the chimney seemed not to have contaminated the ash pellets. The only significant difference in the composition of the pellet samples was in the phosphorus content in the flue-gas treated pellets. This difference is positive, although small (Table 1) and was probably due to the inherent variation in the material's composition.

Compounds present in the flue gas may contaminate the material being dried, for example, with $\mathrm{Si}, \mathrm{Al}$ and $\mathrm{Fe}$ when drying bio-fuels in flue gas [21], and a given level of contamination does occur in ash material over the course of time. In our study, 10 minutes was not long enough to allow a detectable degree of contamination to occur. The flue gas from the boiler passed an electrical precipitator before emission to the atmosphere, and its composition was dependent on the running conditions of the boiler. The current tests were performed at an intermediate load with a high oxygen level (Table 4).

The elemental content in the pellets agree with results from earlier studies on ash from the same boiler [19]. A common phosphorus content of wood ash is $1-2 \%$ [6] and the mean value of $0.3 \%$ is low. In Sweden, the quality of the ash formed is subjective rather than based on the type, and fertilizers using mixed ash from different fuel types is allowed if quality requirements are met [22]. Compared to the recommended SFA values (Table 3), the $\mathrm{P}$ and $\mathrm{Zn}$ content was not sufficient for recycling purposes. However, dolomite adds $\mathrm{Ca}$ and $\mathrm{Mg}$ to the mixture, and dilutes the concentrations of potentially ecotoxic trace metals, such as $\mathrm{Cd}$, As, and Ni. Consequently, levels of these metals of concern were very low. For comparison, up to $200 \mathrm{mgkg}^{-1}$ of $\mathrm{Cd}$ in birch and spruce ash has been determined in other studies [23]. With regard to the mineralogy of the flue-gas treated pellets, our results differ from the data of Holmberg et al. [19] in that no portlandite was found in the ash materials in this study.

\section{Leaching}

Factors that influence the leaching of inorganic constituents from ash materials are: the particle size distribution, test duration, $\mathrm{pH}$, the $\mathrm{L}: \mathrm{S}$ ratio, and the temperature. It is on the first contact with water that the highest concentration of elements is released from the ash material. This can give rise to the so-called "salt effect" on forest soil, and should be avoided. The release of $\mathrm{S}, \mathrm{Cl}, \mathrm{Na}$, and $\mathrm{K}$ from salts and related compounds in ash is generally a rapid process, and leaching of metals, such as $\mathrm{Pb}, \mathrm{Zn}$, and $\mathrm{Cu}$ is commonly suppressed until the $\mathrm{pH}$ of the ash is decreased substantially.

The industrially produced pellet samples were stored in the laboratory for a period of $75 \mathrm{~d}$ before the leaching tests were performed. These pellets were exposed to air in $5 \mathrm{~cm}-$ thick layers in open vessels.

The results from both laboratory leaching tests imply that chemical hardening had occurred in different ways in the pellets that were dehydrated using different methods. Hot-air dehydrated pellets had a high $\mathrm{pH}$ and $\mathrm{EC}$, which suggests 


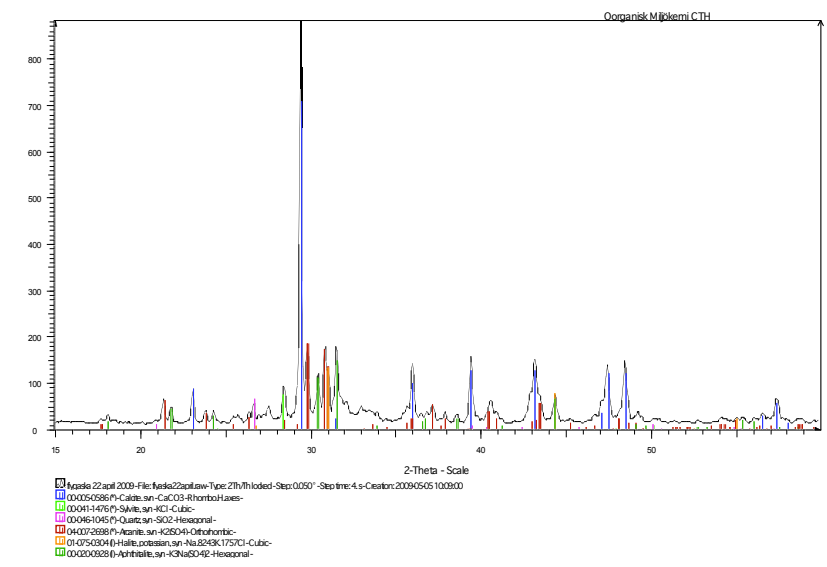

Untreated fly ash

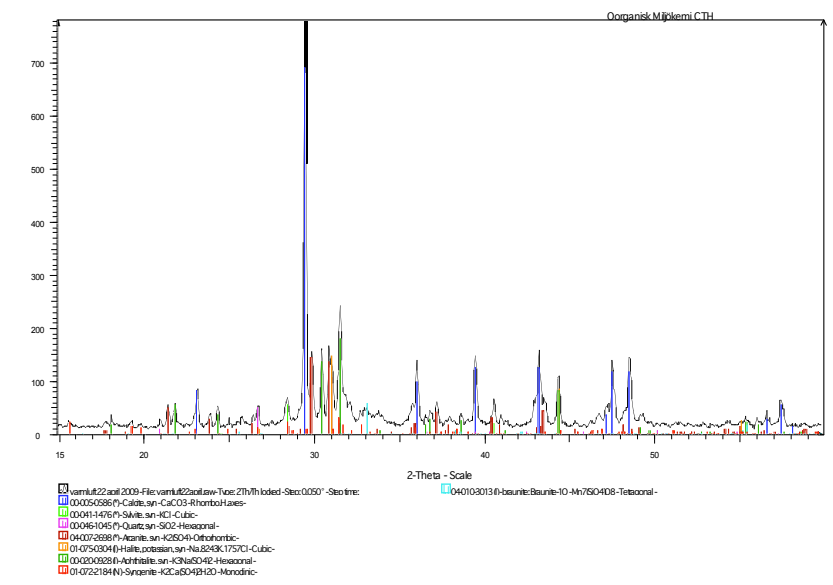

Manually produced pellets of ash, dehydrated in hot air

Fig. (2). Mineralogy of untreated ash and pellets.

that a main part of the $\mathrm{Ca}$ is still present as the hydroxide, which is much more soluble compared to the carbonate. However this was not confirmed by the XRD data. For comparison, the solubility of $\mathrm{Ca}(\mathrm{OH})_{2}$ and $\mathrm{CaCO}_{3}$ is 1.6 and $0.0066 \mathrm{gL}^{-1} \mathrm{H}_{2} \mathrm{O}$, respectively. Dehydration was similarly efficient at both 60 and $130^{\circ} \mathrm{C}$ since both pellets had $\mathrm{pH}>13$ and conductivity $>2000 \mathrm{mS} / \mathrm{m}$. For comparison, the $\mathrm{pH}$ and $\mathrm{EC}$ of fresh, untreated wood ash is 13 and $4500-6400 \mathrm{mS} / \mathrm{m}$, respectively [24]. Pellets dehydrated at room temperature were moist during a longer period of time compared to the hot-air dehydrated pellets, allowing for a longer reaction time (Table 2 ). Their reactivity was intermediate compared to the hot-air and flue-gas treated pellets.

The greatest change was observed in the properties of the flue-gas treated pellets, since the $\mathrm{pH}$ decreased by two units compared to the hot-air treated pellets, and the conductivity also decreased significantly. A 10 min exposure time for flue gas (containing app. $9 \% \mathrm{CO}_{2}$ ) was long enough to achieve a significant reduction of the ash reactivity. Similar results were obtained by $\mathrm{Li}$ et al. [15] and Zhang et al. [25]: accelerated carbonation (up to $100 \% \mathrm{CO}_{2}$ ) lowered the MSWI ash $\mathrm{pH}$ by several units. Treatment times varied from 3 to $10 \mathrm{~h}$ although for $\mathrm{Li}$ et al., this was up to $3 \mathrm{~d}$, and

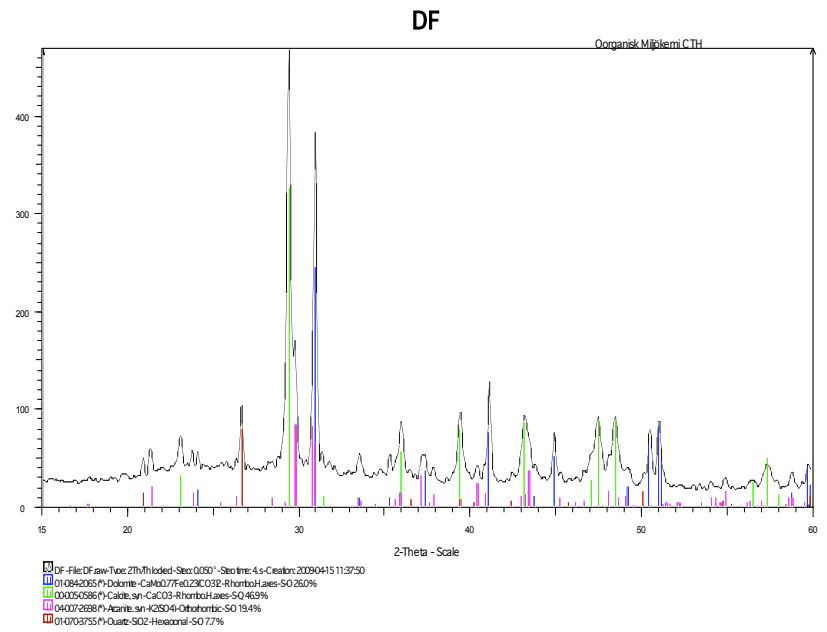

Industrially produced pellets of ash and dolomite, flue-gas treated

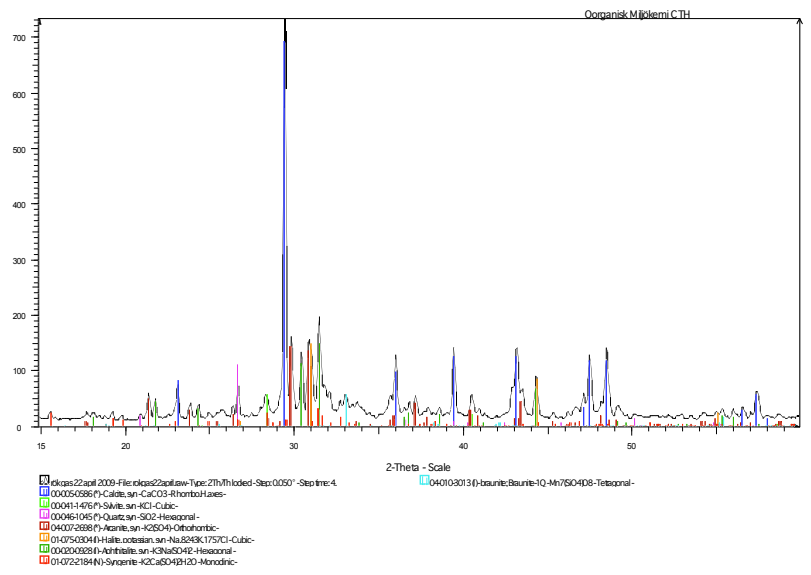

Manually produced pellets of ash, flue-gas treated

elsewhere, Jianguo et al. [16] concluded that $90 \%$ of the reaction takes place in the first $20 \mathrm{~min}$ when carbonating MSWI fly ash for a period of $5 \mathrm{~min}$, followed by $2 \mathrm{~h}$ rotation in bottles, in which the gas was composed of $10-100 \% \mathrm{CO}_{2}$.

It is also possible that the temperature influences the rate of hydration and carbonation of wood ash. For example, the rate of tricalcium silicate hydration in Portland cement increases with increasing temperature [26]. It has also been shown that after the addition of water, coal ash with a high $\mathrm{Ca}$ content had a rapid carbonation rate at $200-230^{\circ} \mathrm{C}$ [27].

The compliance test results support the results from the reactivity tests, and also suggest that chemical hardening had occurred in the different grades in the pellet materials, because the element release patterns differed between the samples (Table 2, Fig. 1). In general, the release of $\mathrm{Ca}$ is suppressed when the $\mathrm{pH}$ exceeds 12 . However, difference in $\mathrm{Ca}$ leaching was significant. The release of $\mathrm{Ca}$ from the fluegas treated pellets was almost eight times lower than that of the pellets dehydrated in hot air (Table 2), and the pellets dehydrated at room temperature released half as much $\mathrm{Ca}$ as the hot-air treated pellets did. 
Table 3. Swedish Threshold Values for Constituents and the Limit Values for the Electrical Conductivity (EC) in Ash Intended for Recycling on Forest Soils

\begin{tabular}{|c|c|c|}
\hline$\%$ (DW) & Minimum & Maximum \\
\hline $\mathrm{Ca}$ & 12.5 & \\
\hline Mg & 1.5 & \\
\hline $\mathbf{K}$ & 3 & \\
\hline $\mathbf{P}$ & 0.7 & \\
\hline $\mathrm{mgkg}^{-1}(\mathrm{DW})$ & & \\
\hline B & & 800 \\
\hline $\mathrm{Cu}$ & & 400 \\
\hline Zn & 500 & 7000 \\
\hline As & & 30 \\
\hline $\mathbf{P b}$ & & 300 \\
\hline Cd & & 30 \\
\hline $\mathrm{Cr}$ & & 100 \\
\hline Hg & & 3 \\
\hline $\mathbf{N i}$ & & 70 \\
\hline V & & 70 \\
\hline
\end{tabular}

\begin{tabular}{|c|c|}
\hline $\begin{array}{c}\text { Dose Tons of Ash (DW) Per } \\
\text { Hectare }\end{array}$ & Limit Value EC $\mathbf{~ S m}^{-1}$ \\
\hline Clear-cut forest & 2400 \\
\hline $\mathbf{2}-\mathbf{3}$ & 2800 \\
\hline $\mathbf{1 ~ - 2}$ & 3200 \\
\hline$<\mathbf{1}$ & 3600 \\
\hline
\end{tabular}

Source SFA (2008).

Table 4. Composition and Properties of the Flue Gas from the Combustion of Sawdust During the Experimental Dehydration of Wood Ash Pellets

\begin{tabular}{|c|c|}
\hline Variable & Value \\
\hline Boiler load (MW) & 24 \\
\hline Flue gas torrent $\left(\mathrm{m}^{3} \mathrm{n} / \mathrm{h}\right)$ & 35516 \\
\hline Flue gas temperature $\left({ }^{\circ} \mathrm{C}\right)$ & 129 \\
\hline $\mathbf{O}_{2}\left(\mathrm{vol}^{2} \mathrm{)}\right)$ & 7 \\
\hline $\mathrm{CO}_{2}\left(\mathrm{vol}^{2}\right)$ & 12 \\
\hline $\mathrm{CO} \mathrm{mg} / \mathrm{nm}^{3}$ at $6 \% \mathrm{O}_{2}$ & 133 \\
\hline $\mathbf{H}_{2} \mathbf{O}(\mathrm{vol} \%)$ & 9 \\
\hline Dust $\mathrm{mg} / \mathrm{nm}^{3}$ at $6 \% \mathrm{O}_{2}$ & 0.11 \\
\hline NOx $\operatorname{mgMJ}^{-1}$ & 52 \\
\hline
\end{tabular}

Potassium and $\mathrm{Na}$ had the highest leaching rates. In general, the release of $\mathrm{K}$ and $\mathrm{Na}$ is not affected by carbonation, as they are readily soluble species bound as sulphates and chlorides, and are leached from all types of ash on contact with water. The exception is the $\mathrm{K}$ that is bound in alkaline feldspars, which is practically insoluble. Steenari et al. [28] observed that the release rate of $\mathrm{K}$ did not decrease on curing, and nearly $80 \%$ from wood ash agglomerates was released during the first leaching step with $\mathrm{L}: \mathrm{S}=16$. In contrast, Li et al. [15] observed a reduced release of $\mathrm{Cl}$ and $\mathrm{SO}_{4}$ from carbonated MSWI fly ash. This is of particular interest in that our results also suggest that flue-gas treatment leads to a decrease in $\mathrm{K}$ leaching. Calcite, sylvite, quartz, arcanite, halite, and aphthitalite are the mineral phases present in both untreated ash and pellets treated with hot air or flue gas. An additional secondary mineral phase was present in the manually produced pellets: syngenite $\left(\mathrm{K}_{2} \mathrm{Ca}\left(\mathrm{SO}_{4}\right)_{2} \mathrm{H}_{2} \mathrm{O}\right)$. Earlier studies confirm that $\mathrm{K}$ is present as arcanite and syngenite in this ash, and that the only $\mathrm{K}$ containing secondary mineral in this ash is syngenite [7]. The solubilities of sylvite, arcanite, and syngenite are 238, 120 and $2.5 \mathrm{~g} / \mathrm{L} \mathrm{H}_{2} \mathrm{O}$, respectively, and so the formation of syngenite could have a positive effect and temporarily slow down the kinetics of $\mathrm{K}$ release from ash materials. The release of $\mathrm{K}$ in forest ecosystems is generally a very rapid process compared to $\mathrm{P}$ and other cations, such as $\mathrm{Ca}$. When cement is stored in paper sacks under high humidity conditions, the formation of lumps can occur owing to the formation of syngenite, because syngenite acts as an effective binder of the dry cement particles [29]. Most of the $\mathrm{K}$ had leached out from the pellets that were dehydrated at room temperature.

Most of the $\mathrm{Mg}$ originates from powdered dolomite rock and its parent mineral, dolomite $\left(\mathrm{MgCa}\left(\mathrm{CO}_{3}\right)_{2}\right)$. The leaching of $\mathrm{Mg}$ is insignificant in the early stages and for low $\mathrm{L}: \mathrm{S}$ ratios. The observed differences in the leached amounts of $\mathrm{Mg}$ were dependent on the $\mathrm{pH}$, and thus are a consequence of the different degrees of carbonation. Only small amounts of $\mathrm{Mn}, \mathrm{Al}, \mathrm{Cu}, \mathrm{Fe}, \mathrm{P}$, and $\mathrm{Zn}$ were released from the pellets, in agreement with earlier studies [8]. At high $\mathrm{pH}$ levels, calcium binds with $\mathrm{P}$ in calcium phosphate compounds that have a low solubility, and becomes more mobile when the $\mathrm{pH}$ decreases below $\mathrm{pH}=8$ [30].

\section{CONCLUSIONS}

A flue-gas treatment offers a route to the rapid drying of ash pellets. A time of $10 \mathrm{~min}$ appears to be short enough such that there is only a limited contamination from the flue gas. The flue-gas treatment resulted in pellets with the lowest reactivity in terms of their $\mathrm{pH}$ and electrical conductivity. In addition, the flue-gas treated pellets released significantly less $\mathrm{Ca}$, but more $\mathrm{Mg}$ compared to pellets treated using other methods. Our results suggest that the formation of syngenite in the $\mathrm{K}$ rich ash material leads to suppressed $\mathrm{K}$ leaching in the flue-gas treated pellets. The reactivity of the pellets dehydrated at room temperature was higher than that of fluegas treated pellets, but was lower than hot-air treated pellets. Moderate $\mathrm{pH}$ and $\mathrm{EC}$ values are important during spreading of wood ash to hinder adverse effects on ground vegetation.

\section{EXTENSIONS AND FUTURE WORK}

Further studies should be undertaken to determine whether the flue-gas treatment time could be decreased further. In addition, the treatment time should be extended to evaluate the risk of contamination from flue gas. All contaminants captured by the ash particles from the flue gas 
will be spread onto forest soil and extensive contamination should be avoided. It is also important to measure the particle size distribution and brittleness in pellets dehydrated using different methods to evaluate the formation of dust during handling and spreading. Dust is unhealthy and increases the risk of occupational diseases. Therefore the durability of carbonated ash particles is another urgent issue to study.

\section{ACKNOWLEDGEMENTS}

The financial support from the Knowledge Foundation, Kalmar University, and Kalmar Energi AB is gratefully acknowledged. Thanks to Joakim Andersson, Camilla Hjelm, and the staff at the district heating plant of Kalmar for help with the pelletizing equipment. We would also like to thank Ronny Torgilsson, Camilla Olofsson, and the staff at the laboratory of Södra Cell Mönsterås for performing the ICP-MS analysis.

\section{REFERENCES}

[1] O. Kellner, and H. Weibull, "Effects of wood ash on bryophytes and lichens in a Swedish pine forest", Scand. J. For. Res., vol. 2, pp. 76-85, January 1998.

[2] S. Jacobson, and L. Gustafsson, "Effects on ground vegetation of the application of wood ash to a Swedish Scots Pine Stand", Basic Appl. Ecol., vol. 2, pp. 233-241, January 2001.

[3] H. Fritze, A. Smolander, T. Levula, V. Kitunen, and E. Mälkönen, "Wood-ash fertilization and fire treatments in a Scots Pine forest stand: effects on the organic layer, microbial biomass and microbial activity", Biol. Fertil. Soils, vol. 17, pp. 57-63, January 1994.

[4] S. Zimmermann, and B. Frey, "Soil respiration and microbial properties in an acid forest soil: effects of wood ash", Soil Biol. Biochem., vol. 34, pp. 1727-1737, January 2002.

[5] L. Etiegni, and A. G. Campbell, "Physical and chemical characteristics of wood ash", Bioresour. Technol., vol. 37, pp. 173178, January 1991.

[6] B-M. Steenari, and O. Lindqvist, "Stabilisation of biofuel ashes for recycling to forest soil", Biomass Bioenergy, vol. 13, pp. 39-50, January 1997.

[7] S. L. Holmberg, and T. Claesson, "Mineralogy of granulated wood ash from a heating plant in Kalmar, Sweden", Environ. Geol., vol. 40, pp. 820-828, February 2001.

[8] P. Mellbo, S. Sarenbo, O. Stålnacke, and T. Claesson, "Leaching of wood ash products aimed for spreading in forest floors - influence of method and L/S ratio", Waste Manage., vol. 28, pp. 2235-2244, December 2008

[9] M. Merlini, G. Atioli, T. Cerulli, F. Cella, and A. Bravo, "Tricalcium aluminated hydration in additivated systems. A crystallographic study by SR-XRPD", Cem. Concr. Res., vol. 38, pp. 477-486, January 2008.

[10] L. G. Karlsson, "Beräkning av kemisk stabilitet hos biobränsleaskor" (In Swedish with English summary), Calculation of the chemical stability of biofuel ashes, Research programme for recycling of wood ash, Sydkraft, NUTEK, Vattenfall, 1997.

[11] C. Gervais, A. C. Garrabrants, F. Sanchez, R. Barna, P. Moszkowicz, and D. S. Kosson, "The effects of carbonation and drying during intermittent leaching on the release of inorganic constituents from a cement-based matrix", Cem. Concr. Res., vol. 34, pp. 119-131, January 2004.

[12] W. A. Klemm, and R. L. Berger, "Accelerated curing of cementitious systems by carbon dioxide", Cem. Concr. Res. Vol. 2, pp. 567-576, January 1972.
[13] T. Svantesson, "Automated Manufacture of Fertilizing Agglomerates from Burnt Wood Ash", Ph.D. thesis, Lund University, Lund, Sweden, 2002.

[14] M. Castellote, C. Andrade, X. Turrillas, J. Campo, and G. J. Cuello, "Accelerated carbonation of cement pastes in situ monitored by neutron diffraction", Cem. Concr. Res., vol. 38, pp. 1365-1373, January 2008.

[15] X. Li, M. Fernándes Bertos, C. D. Hills, P. J. Carey, and S. Simon, "Accelerated carbonation of municipal solid waste incineration fly ashes", Waste Manage., vol. 27, pp. 1200-1206, October 2007.

[16] J. Jianguo, C. Maozhe, Z. Yan, and X. Xin, "Pb stabilization in fresh fly ash from municipal solid waste incinerator using accelerated carbonation technology", J. Hazard. Mater., vol. 161, pp. 1046-1051, January 2009.

[17] E. Andersson, S. Harvey, and T. Berntsson, "Energy efficient upgrading of biofuel integrated with a pulp mill", Energy, vol. 31, pp. 1384-1394, January 2006.

[18] R. Wimmerstedt, "Recent advances in biofuels drying", Chem. Eng. Process., vol. 38, pp. 441-447, January 1999.

[19] S. L. Holmberg, T. Claesson, M. Abul-Milh, and B-M. Steenari, "Drying of granulated wood ash by flue gas from saw dust and natural gas combustion", Resour. Conserv. Recycl., vol. 38, pp. 301-316, January 2003.

[20] Swedish Forest Agency, "Rekommendationer vid uttag av avverkningsrester och askåterföring". (Recommendations in connection with removal of felling residues and ash recycling). Meddelande 2 (In Swedish), 2008.

[21] M. Öhman, A. Nordin, H. Hedman, and R. Jirjis, "Reasons for slagging during stemwood pellet combustion and some measures for prevention", Biomass Bioenergy, vol. 27, pp. 597-605, January 2004.

[22] I. Stupak, A. Asikainen, D. Röser, and K. Pasanen. "Review of recommendations for forest energy harvesting and wood ash recycling", in Sustainable Use of Forest Biomass for Energy. A Synthesis with focus on the Baltic and Nordic Region, D. Röser, A. Asikainen, K. Raulund-Rasmussen, and I. Stupak, Eds., Springer: Dordrecht, pp. 155-196, 2008.

[23] C. Reimann, R. T. Ottesen, M. Andersson, A. Arnoldussen, F. Koller, and P. Englmaier, "Element levels in birch and spruce wood ashes - green energy? ", Sci. Total Environ., vol. 393, pp. 191-197, February 2008

[24] S. L. Holmberg, and T. Claesson, "Limestone and dolomite powder as binders for wood ash agglomeration", Bull. Eng. Geo. Environ., vol. 63, pp. 191-207, May 2004.

[25] H. Zhang, P-J. He, L-M. Shao, and D-J. Lee, "Temporary stabilization of air pollution control residues using carbonation", Waste manage., vol. 28, pp. 509-517, January 2008.

[26] I. Odler, "Hydration, setting and hardening of Portland cement", in Lea's chemistry of cement and concrete, P.C. Hewlett, Ed. Elsevier Butterworth: Heinemann, 1998, p.245.

[27] E. J. Anthony, L. Jia, J. Woods, W. Roque, and S. Burwell, "Pacification of high calcic residues using carbon dioxide", Waste Manage., vol. 20, pp. 1-13, January 2000.

[28] B-M. Steenari, L. G. Karlsson, and O. Lindqvist, "Evaluation of the leaching characteristics of wood ash and the influence of ash agglomeration", Biomass Bioenergy, vol. 16, pp. 119-136, January 1999.

[29] P. J. Jackson, "Portland cement: classification and manufacture", in Lea's chemistry of cement and concrete, P. C. Hewlett, Ed. Elsevier Butterworth: Heinemann, 1998, pp. 50 and 88.

[30] B-M. Steenari, and O. Lindqvist, "Fly ash characteristics in cocombustion of wood with coal, oil or peat", Fuel, vol. 78, pp. 479488, January 1999. 